\title{
PERAN KEPEMIMPINAN KYAI DALAM MENDIDIK DAN MEMBENTUK KARAKTER SANTRI YANG SIAP MENGABDI KEPADA MASYARAKAT
}

\author{
Mia Kurniati, Miftahus Surur, \\ AhmadHafas Rasyidi \\ STKIP PGRI Situbondo
}

\begin{abstract}
Boarding school is an Islamic institution that has a noble goal, that is to educate the community in which is called santri, so that it becomes a human being beneficial to himself more for the outside community. To be a students who hope to be able to be useful in the midst of society, for that institution of boarding schools create a variety of programs and education either in the form of character education and formal education in order to adapt themselves With the demands of the epoch but still on the line of provisions taught his religion that is Islam. In a boarding school certainly has leaders who lead the entire students therein, as the caretaker as well as the main leader of boarding school is a major role in realizing the vision and mission of boarding schools, because only the top The entire activity will run.The method used in this study is a qualitative method in which the source of results is obtained from interviews with predetermined sources. The results of the study prove that the role of the kyai is very urgent for the life of the boarding school community in it,because the kyai is the leader of the boarding school. In realizing a common goal in educating and shaping the character of santri as needed in the midst of society, of course there are several obstacles. However, this is still a reasonable limit and is handled jointly by the kyai together with the administrators of the Salafiyah Dawuhan Islamic boarding school.
\end{abstract}

\begin{abstract}
ABSTRAK
Pondok pesantren merupakan lembaga islam yang memiliki tujuan yang mulia, yakni mendidik masyarakat di dalamnya yang mana disini disebut santri, agar menjadi insan yang bermanfaat bagi dirinya lebih-lebih bagi masyarakat luar. Untuk menjadi santri yang diharap kelak akan mampu berguna ditengah-tengah masyarakat, untuk itu lembaga pondok pesantren menciptakan berbagai macam program dan pendidikan baik berupa pendidikan karakter maupun pendidikan formal agar dapat menyesuaikan diri dengan tuntutan jaman namun tetap pada garis ketentuan yang diajarkan agamanya yaitu agama islam. Dalam sebuah pondok pesantren tentu memiliki pemimpin yang memimpin seluruh santri didalamnya, kyai sebagai pengasuh sekaligus pemimpin utama pondok pesantren merupakan peran utama dalam mewujudkan visi dan misi pondok pesantren, karena hanya atas intruksinyalah seluruh kegiatan akan berjalan. Metode yang digunakan dalam penelitian ini merupakan metode kualitatif yang mana sumber hasil didapat dari hasil wawancara ke narasumber yang sudah ditentukan. Hasil penelitian membuktikan bahwasanya peran kyai begitu sangat urgen bagi kehidupan masyarakat pondok pesantren didalamnya, karena kyai merupakan pemimpin pesantren. Di dalam mewujudkan sebuah tujuan bersama dalam mendidik dan membentuk karakter santri sesuai yang dibutuhkan ditengah masyarakat, tentu terdapat beberapa hambatan-hambatan. Namun hal demikian masih merupakan batas wajar dan ditangani bersama oleh kyai bersama para pengurus pondok pesantren Salafiyah Dawuhan.
\end{abstract}

Kata Kunci : Pesantren, Kyai, Santri, Membentu dan Mendidik, karakter santri, Mengabdi Kepada Masyarakat. 


\section{Pendahuluan}

Di Era Globalisasi sekarang ini sering kita jumpai penyimpangan-penyimpangan perilaku seperti mabuk-mabukan, perampokan, pemerkosaan dan penyimpangan lainnya dari berbagai kalangan terutama anak muda, hal demikian kemungkinan dikarenakan oleh beberapa faktor seperti kurangnya perhatian orangtua, dan hal yang paling utama tentunya kurangnya pemahaman tentang etika dan agama. Kenyataan itu sering meresahkan bagi masyarakat sekitar, melihat betapa banyaknya anak muda yang tidak bisa lagi diandalkan dalam membentuk masyarakat yang harmonis lebih-lebih masa depan kalangan kelompok masyarakat. Masyarakat yang mengharap anak muda dapat menjadi Agen Of Change di masa mendatang seakan musnah.Menurut Buchori (1990) pada jurnal (Agung Prasetyo, 2017) mengemukakan bahwa Perkembangan tekonologi dan informasi dapat mengubah pola pikir, tingkah laku, danpola sikap.Sama halnya dengan globalisasi yang semakin marak dan menjadi tranding topik di telinga masyarakat Indonesia secara umum sekarang ini. Hal demikian sangat jelas bahwa ilmu pengetahuan tentang agama sangat dibutuhkan, Sebagai unit yang independen, maka bagi penganutnya, agama mempunyai kemungkinan yang tinggi untuk menentukan pola prilaku manusia dan bentuk struktur social, dengan demikian ajaran agama (aspek kultural dari agama) mempunyai potensi untuk mendorong atau bahkan menahan proses perubahan sosial dimana dalam agama Islam yang strategis untuk melakukan hal itu adalah ulama dan pendidikan pesantren (Margono, 2011)

Pesantren adalah pusat-pusat pendidikan di Jawa dan Madura yang dikenal dengan istilah pondok. Lebih lanjut lagi, Dhofier mengatakan bahwa pondok barangkali berasal dari kata Arab funduq, yang berarti hotel atau asrama. Hal ini tentu bisa saja benar dikarenakan Pondok pesantren merupakan tempat pendidikan yang menekankan anak didiknya untuk menetap di asrama-asrama.Berkaitan dengan hal ini, jika dibandingkan dengan lembaga pendidikan formal, pondok pesantren dipandang mampu untuk membentuk peserta didik (santri) untuk hidup mandiri. Sistem asrama pada kehidupan pondok pesantren dianggap mampu mendorong karakteristik para peserta didik agar mampu memenuhi dan menjalani tugas kehidupan sehari-hari dengan mandiri (Sanusi, 2012). Namun hal demikian tidaklah luput dari peran kepemimpinan seorang kyai selaku pengasuh atau objek utama dalam mengendalikan segala ketentuan yang berlaku di dalam pesantren. Di dalam pesantren juga para santri akan diajarkan ilmu karakter, yang mana sesuai yang dikutip oleh (Lestari \& Yusmiono, 2018) Menurut Renata dalam (Lestari \& Yusmiono, 2018) pendidikan karakter adalah sebuah sistem yang menanamkan nilai-nilai karakter pada peserta didik, yang mengandung komponen pengetahuan, kesadaran individu, tekad, serta adanya kemauan dan tindakan untuk melaksanakan nlai-nilai, baik terhadap Tuhan Yang Maha Esa, diri sendiri, 
sesama manusia, lingkungan, maupun bangsa, sehingga akan terwujud insan kamil. Oleh sebab itu, pesantren merupakan sarana lengkap bagi para pemuda pemudi dalam menanamkan karakter yang baik dalam diri santri sejak dini, tentu hal tersebut tak luput dari peran kepemimpinan seorang kyai selaku pusat ilmu pagi para segenap Ustad di dalam pondok pesantren.

Para pemimpin pesantren atau dengan kata lain seperti pengasuh pondok pesantren, yaitu Kyai dan nyai adalah tokoh utama dalam proses ini. Transimisi ilmu yang dilakukan oleh seorang Kyai dan nyai berlangsung secara monolog, mengingat posisi tradisional mereka sebagai pemegang otoritas keagamaan. Oleh karena itu, transmisi keilmuan yang berlangsung di pesantren lebih bersifat dogmatis dan ideologis menurut Ema dalam jurnal (Hartono, 2016). Keberadaan Kyai dan pesantren merupakan satu kesatuan yang tidak dapat dipisahkan karena figur Kyai sangatlah dominan dalam menentukan segala kebijakan, pengelolaan dan pengembangan pondok pesantren. Kyai dengan karismanya dan kemampuan dapat mengolah pondok pesantren dengan baik sebagai pionir pendidikan Islam di Indonesia. Sebagaimana pada umumnya, Kyai di samping sebagai pemimpin pesantren juga sekaligus sebagai pemilik. Sebagai pemilik, tentu saja semua kebijakan perkembangan baik fisik maupun non fisik pesantren bersumber dari Kyai. Peran Kyai yang sedemikian signifikan ini menjadi ciri pondok pesantren itu sendiri. Kyai, identik dengan sebutan ulama, keduanya merupakan gelar bagi orang sholeh yang berilmu, dan memiliki kharisma, para kyai atau ulama adalah pewaris Nabi dan menjadi tauladan bagi masyarakatnya. Seorang dikatakan kyai sejati apabila zahid, arif, mendalami ilmu-ilmu syariat dan memahami masalah ummat terutama yang selalu ia terapkan kepada santr-santrinya. (An'im, 2010)

Santri sebagai masyarakat di dalam lingkungan pesantren memiliki latar belakang yang berbeda-beda, sama seperti kebanyak karakter orang diluar pesntren yang beragam. untuk itu, tak mudah menyesuaikan diri dengan peraturan yang berlaku di dalam pondok pesantren, disinilah peran seorang kyai yang paling utama dalam mengatasi hal yang demikian. Berusaha Menyelaraskan karakter masing-masing santri tentu bukan hal yang mudah untuk diatasi oleh seorang kyai, namun hal demikian tentu saling bekerja sama dengan para jajaran kepengurusan yang sudah dibentuk di pondok pesantren.

\section{Kajian Teori}

1. Pesantrenmerupakan lembaga pendidikan islam tertua di indonesia, para alumni yang lulus dari pondok pesantren telah banyak kita temui di tengah-tengah masyarakat luas dengan kinerjanya yang memuaskan, Pesantren juga merupakan lembaga pendidikan yang unik, tidak saja karena keberadaannya yang sudah 
sangat lama, tetapi juga karena kultur, metode, dan jaringan yang diterapkan oleh lembaga tersebut.

2. Kyai identik dengan sebutan ulama, kyai (Pengasuh) mempunyai peranan tertinggi dalam sebuah kegiatan pesantren dan kyai juga tidak hanya fokus dalam kegiatan di pesantren, namun kyai juga menjadi tokoh agama sekaligus tokoh suri tauladan yang baik di masyarakat dan lingkungannya. Kyai adalah figur dengan kapasitas pribadi yang sarat dengan bobot kualitatif, bobot kualitatif inilah yang menjadikan sosok. Peran kyai dalam lembaga pendidikan di pesantren tidak hanya sebagai pengasuh yang mendirikan lembaga pendidikan pondok pesantren atau pemilik pesantren, namun kyai juga yang mengatur proses belajar mengajar para santri, dan kyai juga sebagai penjaga serta pembimbing moral ummat/masyarakat.

3. Santri merupakan masyarakat yang menghuni pondok pesantren dengan tujuan menuntut ilmu dalam jangka waktu yang tak terbatas. selama ia menuntut ilmu di dalam pondok pesantren, selama itu pula gelarnya menjadi santri dan harus patuh kepada peraturan yang ditentukan oleh pengasuh pondok pesantren yang dalam hal ini ialah kyai. Ilmu yang sudah didapat di pondok pesantren diharapkan mampu bermanfaat di kalangan masyarakat.

4. Mengabdikan diri kepada masyarakat merupakan suatu keharusan dan kewajiban seorang santri yang sudah menuntut ilmu di dalam pondok pesantren, karena selama menuntut ilmu di dalam pondok pesantren, santri sudah dibekali dengan berbagai ilmu pengetahuan baik ilmu pengetahuan pendidikan maupun ilmu pengetahuan agama, sehingga santri lulusan pondok pesantren sangat tau kebutuhan masyarakat sekitar. dalam kategori ini, santri sangat bisa diandalkan dalam berbagai hal apapun.

\section{Metode Penelitian}

Penelitian ini dilakukan dengan menggunakan metode Kualitatif, yaitu metode yang diarahkan pada latar dan individu secara holistic (utuh) melalui wawancara ke berbagai sumber untuk mendapatkan jawaban dari pertanyaan yang dibuat oleh peneliti. Populasi dalam penelitian ini adalah pondok pesantren Salafiyah Dawuhan Situbondo - Jawa Timur.

\section{Pembahasan dan Hasil Penelitian}

\section{Sejarah Pondok Pesantren Salafiyah Dawuhan}

Berawal dari keistiqamahan KH. Abd. Rasyid yang ikhlas dan sabar membimbing pelaksanaan pengajian rutin setiap Jum'at legi dan Jum'at kliwon, Beliau mampu melahirkan lembaga pendidikan islam, berupa Pondok Pesantren. Pengajian yang berlangsung sejak tahun 1980an hingga hari ini memiliki jama'ah yang cukup banyak dan sebarannya pun 
bukan hanya meliputi daerah setempat, akan tetapi juga meliputi wilayah Surabaya, Madura, Bali hingga Yogyakarta.

Dalam perkembangan selanjutnya, di awal tahun 2012 muncul permintaan dari para jama'ah pengajian untuk mendirikan pondok pesantren yang dapat menampung putra-putri para jama'ah dalam mempelajari ilmu agama. Maka dibangunlah asrama pondok bambu yang sangat sederhana dalam menunjang santri, 3 (tiga) bilik untuk santri putra dan untuk santri putri 3 (tiga) bilik pula. Ke enam asrama tersebut dibangun di atas tanah milik KH. Abd. Rasyid pribadi, hingga awal tahun 2015 berkat bantuan dana pemerintah dibangunlah rusunawa yang dikhususkan untuk santri putri, dengan adanya bantuan pemerintah tersebut kini santri putri memiliki bangunan asrama berlantai tiga dengan belasan ruangan, keadaan yang patut disyukuri bagi segenap warga pondok pesantren sehingga pihak pengurus pesantren tidak perlu lagi memikirkan ruang tambahan untuk santri baru yang meningkat kian pesat.

Pada awal berdirinya, santri yang mondok di Pondok Pesantren ini berjumlah 11 (sebelas) orang, namun berkat kegigihan dan semangat para jama'ah pengajian dalam menyebarkan ajaran agama yang dipimpin oleh KH.Abd Rasyid sehingga dalam hitungan beberapa bulan saja jumlah santri semakin bertambah banyak, hingga sampai saat ini jumlah santri seluruhnya mencapai hampir 200 orang.

\section{Kurikulum Pondok Pesantren Salafiyah Dawuhan Situbondo}

Kurikulum Pondok Pesantren Salafiyah Dawuhan Situbondo jawa-timur terdiri dari intrakulikuler, kokurikuler dan ekstrakulikuler. Intrakulikuler pada kurikulum pondok pesantren salafiyah dawuhan situbondo secara khusus mengajarkan materi-materi kejuruan, sedangkan Ekstrakulikuler pada kurikulum pondok pesantren salafiyah yang bersifat campuran adalah dengan mengajarkan semua bidang ilmu agama mulai dari Fikih, Hadist, Tafsir Juga tauhid yang dikemas dalam sebuah lembaga Madrasah Diniyah. Fokus penekanan kurikulum kokulikuler di pondok pesantren salafiyah dawuhan secara khusus juga menerapkan pembelajaran campuran seperti bidang ilmu alat yang meliputi: ilmu Tajwid atau ilmu Al-Qur'an yang dikemas dalam Madrasut Ta'mil Qur'an, sedangkan ilmu nahwu dan ilmu saraf dikemas dalam Madrasah Amtsilati. Guna menyalurkan bakat dan minat para santri pondok pesantren salafiyah dawuhan meluncurkan beberapa kegiatan ekstrakulikuler meliputi: Qori'ah, Kursus Bahasa Arab, Hadrah, Daul (Musik Tradisional Kontemporer).

Sebagaimana pesantren pada umumnya yang orientasi kegiatannya untuk mencetak masyarakat madani yang religious, humanis dan nasionalis, kedisiplinan menjadi prioritas 
utama dalam pelaksanaan kegiataan apapun, tak terkecuali Pondok Pesantren Salafiyah Dawuhan Situbondo. Oleh karenanya, Waktu yang digunakan dalam kegiatan pembelajaran di dalam pondok pesantren salafiyah dawuhan dimulai selepas melaksanakan sholat subuh hingga pukul 22:00 WIB kecuali terdapat kegiatan-kegiatan khusus.

Dalam kurikulumnya, kyai menitik beratkan pada satu kegiatan tambahan yang sangat dianjurkan kepada santri untuk selalu mengadakan Istghosah setiap malam. Oleh kyai, kegiatan istighosah yang diwajibkan kepada seluruh santri yang dilakukan setiap malam agar supaya santri dapat menutup kegiatan yang terbilang sangat padat dengan mengingat dan menyatu dengan Allah SWT. yang mana dalam artiannya, santri dilatih untuk menutup kegiatannya dengan bertawassul kepada Allah SWT dikarenakan santri sudah memulai kegitan dengan melaksanakan kewajiban sholat subuh. Selain itu juga, kyai dalam menurunkan perintah istighosah tersebut agar santri selalu mendoakan kedua orang tuanya supaya dilancarkan rezekinya, kedua orang tua yang berusaha keras demi membiayai anaknya yang mencari ilmu di pondok pesantren. Selain melancarkan rezeki, melakukan istighosah secara rutin dan istiqomah tentu mendatangkan banyak manfaat baik lahirian maupu batiniah bagi para pengamalnya.

Adapun tujuan Istighotsah menurut Ash-Shiddiqy di dalam bukunya yang berjudul Pedoman Dzikir dan doa yang dikutip oleh (Ade Saputra, 2018) dalam jurnnalnya yaitu sebagai alat mendekatkan dan menyandarkan diri kepada Allah. Orang yang berdzikir (mengingat Allah) senantiasa merasa dekat dengan-Nya dan Allah bersamanya. Kebersamaan ini bersifat khusus, bukan kebersamaan karena bersanding, tetapi kebersamaan karena kedekatan, cinta, pertolongan dan taufiq.

Selain pemaparan tujuan istighosah diatas, tujuan istighosah juga dipaparkan oleh (Syafii Mufid, 1985) yakni di dalam Istighotsah tekandung usaha- usaha pemuasan dan kerelaan dan kesadaran yang sejati. Dalam kontek yang semacam ini dapat diketahui bahwa Istighotsah bertujuan sebagai berikut:

a. Sebagai sarana untuk mendekatkan diri kepada Allah SWT.

b. Sebagai sarana menambah rasa iman, pengabdian dan kematangan cita- cita hidup.

c. Sebagai sarana pengendalian diri, pengendalian nafsu yang sering menjadi penyebab kejahatan.

3. Analisis Data Tentang Peran Kyai Sebagai Pengasuh Dalam Mendidik Dan Membentuk Karakter Santri Salafiyah Dawuhan Agar Mampu Mengabdi Kepada Masyarakat 
Sosok peran kyai dalam sebuah pondok pesantren tentunya memiliki posisi yang sangat urgent, mengingat bahwa kyai sebagai pengasuh yang mana santrinya terpaku teguh pada perintah sang kyai yang mana telah banyak kita saksikan di media-media tentang gambaran seorang santri terhadap gurunya, sehingga disitulah perlu diteliti tentang betapa pentingnya peran seorang kyai.

Dalam usahanya mendidik santri dan membentuk karakter mulia yang diharap kelak mampu mengamalkan ilmunya kepada masyarakat, kyai tentu memiliki strategi tersendiri, setelah dilihat dari hasil wawancara bersama pengasuh yang dilaksanakan pada hari sabtu tanggal 06 Juli 2019, disini dapat kami simpulkan bahwa kyai tidak muluk-muluk dalam membuat srategi yang menekankan pada sikap karakter seorang santri, hal demikian dapat kita baca melalui hasil wawancara bersama pengasuh pondok pesantren islam Salafiyah Dawuhan Situbondo:

"untuk strategi mendidik dan membentuk karakter santri, disini saya lebih memfokuskan kepada bagaimana menanamkan ketaatan pribadi santri. Sebab allah lebih menyukai hambanya yang taat dari pada hambanya yang pintar, karna orang pintar belum tentu taat, namun dengan ketaatan, seorang hamba begitu dengan mudanya akan dipintarkan oleh allah. Dalam memimpin santri, saya mengajarkan mereka tentang ajaran Ki Hajar Dewantara yang berbunyi ing ngarso sung tulodo, ing madyombangun karso, Tut wuri handayani"

Pada penjelasan diatas, KH. Abd Rasyid sudah menjelaskan bagaimana beliau berusaha menanamkan ketaatan kepada santri, sebab betapa mulianya kedudukan seseorang yang taat bagi allah SWT. Dengan ketaatan, manusia sangat mudah memperoleh kepintaran dengan sendirinya. Kemudian selain mengutamakan ajaran ketaatan kepada para santrinya, kyai juga mengamalkan ajaran Ki Hajar Dewantara yakni ing ngarso sung tulod artinya Ing ngarso itu didepan / dimuka, Sun berasal dari kata Ingsun yang artinya saya, Tulodo berarti tauladan. Jadi makna Ing Ngarso Sung Tulodo adalah menjadi seorang pemimpin harus mampu memberikan suri tauladan bagi orang - orang disekitarnya. Sehingga yang harus dipegang teguh oleh seseorang adalah kata suri tauladan. Sedangkan Ing Madyo Mbangun Karso, Ing Madyo artinya di tengah-tengah, Mbangun berarti membangkitan atau menggugah dan Karso diartikan sebagai bentuk kemauan atau niat. Jadi makna dari kata itu adalah seseorang ditengah kesibukannya harus juga mampu membangkitkan atau menggugah semangat. Karena itu seseorang juga harus mampu memberikan inovasi-inovasi dilingkungannya dengan menciptakan suasana yang lebih kodusif untuk keamanan dan kenyamanan. 
Demikian pula dengan kata Tut Wuri Handayani, Tut Wuri artinya mengikuti dari belakang dan handayani berati memberikan dorongan moral atau dorongan semangat. Sehingga artinya Tut Wuri Handayani ialah seseorang harus memberikan dorongan moral dan semangat kerja dari belakang. Dorongan moral ini sangat dibutuhkan oleh orang - orang disekitar kita menumbuhkan motivasi dan semangat (Suparti, 2013).

Jadi secara tersirat kyai mengajarkan kepada santrinya supaya kelak setelah lulus dari pondok pesantren diharapkan dapat memberi contoh figur yang baik dan disamping menjadi suri tauladan atau panutan, tetapi juga harus mampu menggugah semangat dan memberikan dorongan moral dari belakang agar orang - orang disekitarnya dapat merasa situasi yang baik dan bersahabat . kata beliau lagi :

"Selain itu, saya berusaha mengajari mereka dengan memberi contoh yang baik juga memberi mereka semangat. Dalam mendidik dan mengajari para jamaah dan santri saya dalam menanamkan pohon-pohon ilmu pada pribadinya masing-masing agar supaya dalam setiap ucapan dan perbuatannya mengeluarkan ilmu. Sesuai dengan hadist Rasulallah SAW Al imamu uryana walibasutat wajihatul haya yang artinya iman itu telanjang, bajunya adalah ketakwaan, dan perhiasannya adalah nahwu. Dan untuk menjadi takwa, manusia tdak bisa mencapainya tanpa imbingan seorang guru, sebab ketakwaan masalah rasa, jadi perlu untuk dibiming oleh seorang guru"

Dan penjelasan terakhir diatas sudah terlihat jelas tentang betapa beliau sangat mencontoh sikap Rasulullah dalam mendidik umatnya yakni memberi contoh langsung melalui perbuatan yang dermawan dan ketegasan beliau, hal demikian juga betapa kyai menanamkan pemahaman kepada santri tentang pentingnya sebuah ketakwaan. Didalam jurnalnya (Sulaiman, 2016) memaparkan tentang keteladanan yang mana Kecenderungan mencontoh itu sangat besar pengaruhnya pada anak-anak, sehingga sangat besar pengaruhnya bagi perkembangan. Sesuatu yang dicontoh, ditiru, atau diteladani itu mungkin yang bersifat baik dan mungkin pula bernilai keburukan. Untuk itu bagi umat Islam, keteladanan yang paling baik dan utama, terdapat di dalam diri dan pribadi Rasulullah Muhammad SAW sebagaimana firman Allah SWT :

Artinya: "sesunngguhnya telah ada pada (diri) Rasulullah itu suri tauladan yang baik"

Dalam proses pendidikan berarti setiap pendidik harus berusaha menjadi teladan yang baik bagi anak didiknya. Dengan keteladanan itu diharapkan anak didik akan mencontoh segala sesuatu yang baik di dalam perkataan maupun perbuatan pendidiknya.

Pada dasarnya, adanyapondok pesantren bukan semata-mata lembaga pendidikan yang mengajarkan, mengembangkan dan menyebarkan ilmu agama Islam, melainkan juga 
lembaga kemasyarakatan yang memiliki fungsi amal terhadap masyarakat serta hubungan tata nilai dengan kultur masyarakat,khususnyayang ada dalam lingkungan pengaruhnya. Idealnya,pesantren bukan hanya lembaga yang menyelenggarakan kegiatan pendidikan bagi para santrinya,namun bisa mengayomi masyarakat sekitarnya serta menggerakkan roda-roda perekonomian masyarakat sekitarnya, hal tersebut dipaparkan jelas oleh Dawam Rahardjo dan Rahim dalam kutipan naskah (R. Ibrahim, 2016).

\section{Kesimpulan}

1. Peran kyai Dalam pembentukan karakter santri Salafiyah Dawuhan

Kyai memiliki peran yang sangat penting dalam membentuk karakter santri, mulai dari menetapkan peraturan yang berlaku di pesantren hingga turun langsung ke lapangan memberi pengarahan baik yang mana keseluruhannya dapat dilaksanakan dengan baik oleh para santri.

2. Peran kyai sebagai orang tua terhadap santri Salafiyah Dawuhan

Pesantren merupakan asrama bagi santri yang mencari ilmu diwajibbkan bermukin di pesantren, sehingga diasrama tersebut santri secara 24 jam terus berada dilingkungan pesantren, disitulah peran kyai sebagai orang tua bagi santri sangat dibutuhkan. Kyai yang berperan sebagai orang tua tak pernah luput dalam memberikan perhatian kepada segenap santri, Yang mana selain pengurus pesantren kyai juga ikut andil dalam pembentukan karakter pesantren, kyai memberi pengarahan langsung atau tidak langsung dengan melalui pengurus pesantren.

3. Peran pengurus pesantren sebagai penerima mandat kyai dalam pembentukan karakter santri Salafiyah Dawuhan

Didalam pondok pesantren, kepengurusan juga memiliki peran yang sangat penting dalam membentuk karakter santri, hal demikian sangat jelas ketika kyai mengamanahkan kepada para pengurus agar para santri benar-benar dididik dengan baik sesuai dengan peraturan dan ketetapan yang disahkan oleh kyai sebagai pengasuh pesantren Salafiyah Dawuhan. Kemudian setelah mendapatkan amanah dari kyai, ketua pengurus mengerahkan seluruh anggota kepengurusan untuk melaksanakan amanah kyai tersebut.

4. Hambatan-hambatan dalam mendidik dan membentuk karakter santri Salafiyah Dawuhan

Santri yang datang dari berbagai daerah tentu memiliki karakter dan sifat bawaan yang berbeda-beda. Sehingga hal demikian menjadi tantangan bagi para pengurus lebih-lebih 
kyai sendiri sebagai pengasuh, namun dengan pengawasan dan pelayanan langsung dri para pengurus dapat mengurangi sifat-sifat yang kurang baik bagi santri. Kenakalan-kenakalan yang sering terjadi di pesantren masihlah diatas batas kenakalan-kenakalan remaja pada umumnya, sehingga tidak butuh waktu lama untuk mengajarkan mereka tentang tata karma dan ilmu-ilmu keislaman.

\section{Daftar Pustaka}

Ade Saputra, M. (2018). Pengaruh kegiatan istighosah terhadap kecerdasan spiritual siswa di sman 1 pacet mojokerto skripsi.

Agung Prasetyo, D. (2017). Pentingnya Pendidikan Kewarganegraan Untuk Mempersiapkan Diri. Prosiding Seminar Nasional Tahunan Fakultas Ilmu Sosial Universitas Negeri Medan, 1(1), 191-196.

An'im, A. (2010). Petuah Kyai Sepuh (seri satu; B. Idhoh, ed.).

Hartono, R. (2016). Pola Komunikasi di Pesantren : Studi tentang Model Komunikasi antara Kiai , Ustadz, dan Santri di Pondok Pesantren TMI Al-Amien Prenduan. 5704.

Latif, D. (1983). Kedudukan dan Kekuasaan Peradilan Agama di Indonesia. Jakarta.

Lestari, N. D., \& Yusmiono, B. A. (2018). (Jurnal Manajemen, Kepemimpinan, dan Supervisi Pendidikan) Volume 3, No. 1, Januari-Juni 2018. (Jurnal Manajemen, Kepemimpinan, Dan Supervisi Pendidikan), 3(1), 114-125.

Margono, H. H. (2011). KH . Hasyim Asy 'ari dan Nahdlatul Ulama: Perkembangan Awal dan Kontemporer. 26(3).

Sanusi, U. (2012). manusia Indonesia yang harus dikembangkan oleh setiap satuan pendidikan . Oleh. 10(2), 123-139.

Sulaiman, M. (2016). MENDIDIK DENGAN TAULADAN. 11(1), 104-122.

Suparti, W. (2013). IMPLEMENTASI TRILOGI KI HAJAR DEWANTARA DALAM KEPEMIMPINAN KEPALA SEKOLAH DI SMA TAMAN MADYA IBU PAWIYATAN YOGYAKARTA. 2(SGEM2016 Conference Proceedings, ISBN 978-619-7105-16-2 / ISSN 1314-2704), 1-39.

Syafii Mufid, A. (1985). Zikir Sebagai Pembinaan Kesejahteraan Jiwa. Surabaya : Bina Ilmu. 